\title{
PENGARUH KESEHATAN DAN KESELAMATAN KERJA (K3) TERHADAP KINERJA KARYAWAN PT. BEKAERT INDONESIA PLANT KARAWANG
}

\author{
Pupung Purnamasari ${ }^{(1)}$, Abdillah ${ }^{(2)}$ \\ Sekolah Tinggi Ilmu Ekonomi Pertiwi Bekasi \\ Pupung.purnamasari@pertiwi.ac.id \\ abdillah@bbc-ets.com
}

\begin{abstract}
ABSTRAK
Penelitian ini bertujuan untuk mendapatkan pengetahuan yang sahih (valid) dan dapat dipercaya (reliable) tentang sejauh mana Pengaruh Kesehatan dan Keselamatan Kerja (K3) terhadap kinerja karyawan PT. BEKAERT INDONESIA yang beralamat di Kota Industri Suryacipta Jl. Surya Utama Kav 1-14 Teluk Jambe - Karawang. Penelitian ini dilakukan pada bulan Desember 2015 s/d Mei 2016. Metode analisis data yang digunakan adalah metode analisis deskriptif dan metode analisis kuantitatif. Jumlah sampel sebanyak 60 orang karyawan diperoleh dengan teknik convenience sampling. Instrumen yang digunakan adalah kuesioner atau angket yang berbentuk skala ordinal dengan kategori 1 sampai dengan 5 .

Penelitian ini menggunakan metode koefesien korelasi yang bertujuan untuk mengetahui tingkat hubungan antara variabel $\mathrm{X}$ dan variabel $\mathrm{Y}$. Dalam penelitian ini peneliti memperoleh nilai korelasi sebesar $(r)=0,615$. Hal ini menunjukkan bahwa hubungan antara kesehatan dan keselamatan kerja dan kinerja karyawan adalah positifdan kuat. Kemudian dilakukan uji t untuk menunjukkan bahwa keselamatan kerja telah terbukti berpengaruh terhadap kinerja karyawan pada PT. BEKAERT INDONESIA.Hal itu dibuktikan dengan diterima hipotesis H1 yang berbunyi "kesehatan dan keselamatan kerja berpengaruh terhadap kinerja karyawan pada PT. BEKAERT INDONESIA." Kesimpulan tersebut diperoleh dari hasil perhitungan uji signifikansi (uji t) dimana nilai t hitung $(5,621)$ lebih besar dari pada t tabel $(1,671)$.

Berikutnya analisis data dilakukan dengan melakukan analisis regresi sederhana. Dengan metode analisis regresi sederhana peneliti memperoleh persamaan yang dapat digunakan untuk memprediksi kinerja karyawan melalui variabel kesehatan dan keselamatan kerja di PT. BEKAERT INDONESIA. Persamaan regresi yang diperoleh adalah $Y=39,12+0,587 X$. Variable X (Kesehatan Dan Keselamatan Kerja) bernilai positif yaitu sebesar 0,587. Itu artinya bahwa Kesehatan Dan Keselamatan Kerja mempunyai pengaruh yang positif atau berbanding lurus terhadap Kinerja Karyawan. Sedangkan dari perhitungan uji koefesien determinasi menunjukkan bahwa kesehatan dan keselamatan kerja memberikan kontribusi terhadap kinerja karyawan sebesar 37,82\% dan sisanya (sebesar 62,18\%) dipengaruhi oleh faktor lain.
\end{abstract}

Key word: kesehatan, keselamatan kerja, dan kinerja karyawan

\section{PENDAHULUAN}

Sumber daya manusia merupakan peranan penting bagi keberhasilan suatu organisasi atau perusahaan, karena manusia merupakan aset hidup yang perlu dipelihara dan dikembangkan. Oleh karena itu karyawan harus mendapatkan perhatian yang khusus dari perusahaan. Kenyataan bahwa manusia sebagai aset utama dalam organisasi atau perusahaan, harus mendapatkan perhatian serius dan dikelola dengan sebaik mungkin. Keselamatan dan kesehatan kerja merupakan

Hak Asasi Manusia (HAM). Untuk itu, kesadaran mengenai pentingnya K3 harus selalu di gugah, diingatkan, serta di budidayakan di kalangan para pekerja. Pemahaman dan 
pelaksanaan K3 di perusahaan sangat diperlukan, terutam dalam syarat - sayarat kerja. Hal ini berkaitan dengan masalah perlindugan tenaga kerja terhadap kecelakan kerja, guna meminimalisir kemungkinan terjadinya kecelakaan kerja, perlu pemahaman dan pelaksanaan K3 secara baik dan benar.

PT. BEKAERT INDONESIA merupakan salah satu prusahaan asing yang berada di Indonesia yang bergerak dalam bidang manufaktur baja. PT. BEKAERT adalah salah satu perusaahan yang memproduksi berbagai jenis wire yang mana hingga saat ini terdapat beberapa divisi produksi yang memproduksi produk dengan bahan baku yang sama akan tetapi memiliki jenis yang berbeda. Terdapat empat produk yang kami produksi diantaranya ; Steel cord, Wire, Dramix dan ISC.

Kesehatan dan keselamatn kerja beserta resiko yang timbul akibat kerja sering kali terjadi di divisi ini seperti; kebakaran mesin, ketakutan aliran listrik, terpotong, luka memar, keseleo, patah tulang, kerugian alat tubuh, penglihatan dan pendengaran. Oleh karena itu jaminan kesehatan dan keselamatan kerja sangatlah penting untuk meningkatkan kinerja karyawan.

\section{METODE PENELTIAN}

Dunia kerja sangatlah rentan dengan yang namanya suatu kecelakaan kerja, oleh karenanya pemerintah pun mengatur K3 dalam sebuah perundang - undangan yang mana dalam hal ini setiap kegiatan usaha harus mematuhi peraturan yang telah di tentukan oleh pemerintah. Metode analisis data yang digunakan adalah metode analisis deskriptif dan metode analisis kualitatif.

Metode analisis deskriptif yaitu metode yang bertujuan untuk mengumpulkan data dan informasi yang dapat menggambarkan keadaan objek penelitian dan menyederhanakannya untuk menjelaskan masalah dan pemecahannya agar dapat dibaca dan mudah dimengerti. Tujuan dari penggunaan metode ini adalah untuk mengetahui K3 dan kinerja karyawan yang terdapat di PT. BEKAERT INDONESIA.

Pada penelitian ini menggunakan teknis analisis data secara kuantitatif yakni teknik analisis berupa angka-angka yang dilakukan perhitungan untuk menganalisa kondisi dan perilaku data sehingga melalui hasil perhitungan tersebut akan diketahui pengaruh, gambaran, dan penarikan kesimpulan dari data tersebut. Lokasi penelitian bertempat di PT. BEKAERT INDONESIA Kota Industri Suryacipta J1. Surya Utama Kav 1-14 Teluk Jambe - Karawang 41361, Karawang. 


\section{HASIL DAN PEMBAHASAN}

Dalam memperoleh data dalam penelitian ini, peneliti menggunakan kuesioner yang dibagikan kepada sampel di PT. BEKAERT INDONESIA. Secara teknis peneliti memakai teknik penyebaran kuesioner dengan cara convenience sampling, yang dalam Hamid (2010:18) convenience sampling berarti unit sampel yang ditarik mudah dihubungi, tidak menyusahkan, mudah untuk mengukur, dan bersifat kooperatif. Yang menjadi sampel dalam penelitian ini adalah karyawan di PT. BEKAERT INDONESIA Dep. Produksi Div. steel cord team A, dan jumlah sampel dalam penelitian ini sebanyak 60 orang.

Dalam kuesioner tersebut masing-masing pernyataan dijawab dengan menggunakan Skala Ordinal. Skala ordinal yang digunakan adalah STS (Sangat Tidak Setuju = 1), TS (Tidak Setuju = 2), KS (Kurang Setuju = 3), S (Setuju =4), dan SS (Sangat Setuju = 5).

Dari output hasil perhitungan menggunakan software SPSS versi 16 tersebut diperoleh nilai minimum dari K3 pada PT. BEKAERT INDONESIA adalah 63 dan nilai maksimumnya adalah 96. Selain itu diperoleh pula nilai mean (rata-rata) sebesar 78,98 dengan standar deviasi sebesar 8,024. interprestasi skor teoritis (Variabel X) min 20 menunjukan nilai STS (Sangat Tidak Setuju), max 100 menunjukan nilai SS (Sangat Setuju) dengan rentang skor $80: 5=16$.

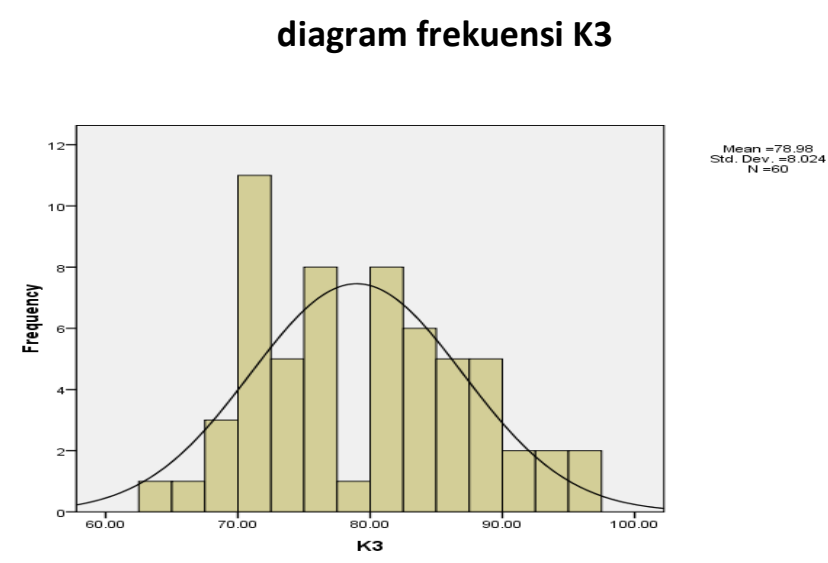

Tabel interpretasi skor teoritis variabel $\mathrm{K} 3(\mathrm{X})$

\begin{tabular}{|c|c|c|}
\hline No & Rentang Skor & Inetrpretasi \\
\hline 1 & $20,0-36,0$ & STS \\
\hline 2 & $36,1-52,0$ & TS \\
\hline 3 & $52,1-68,0$ & KS \\
\hline 4 & $68,1-84,0$ & S \\
\hline 5 & $84,1-100$ & SS \\
\hline
\end{tabular}

Berdasarkan tabel interpretasi skor teoritis di atas, maka dapat kita ketahui bahwa kondisi K3 pada PT. BEKAERT INDONESIA adalah Setuju dan ini mengartikan kondisi 
yang BAIK, hal ini di tunjukan oleh nilai rata - rata score pada tabel descriptive statistics yang menunjukan point 78,98 dan nilai ini berada pada kondisi BAIK pada tabel interpretasi skor teoritis.

Sedangkan Maka melalui output hasil perhitungan menggunakan software SPSS versi 16 diperoleh nilai minimum dari kinerja karyawan pada PT. BEKAERT INDONESIA adalah 65 dan nilai maksimumnya adalah 104. Selain itu diperoleh pula nilai mean (rata-rata) sebesar 85,48 dengan standar deviasi sebesar 7,657. interprestasi skor teoritis (Variabel Y)

min 22 menunjukan nilai STS (Sangat Tidak Setuju), max 110 menunjukan nilai SS (Sangat Setuju) dengan rentang skor $88: 5=17,6$.

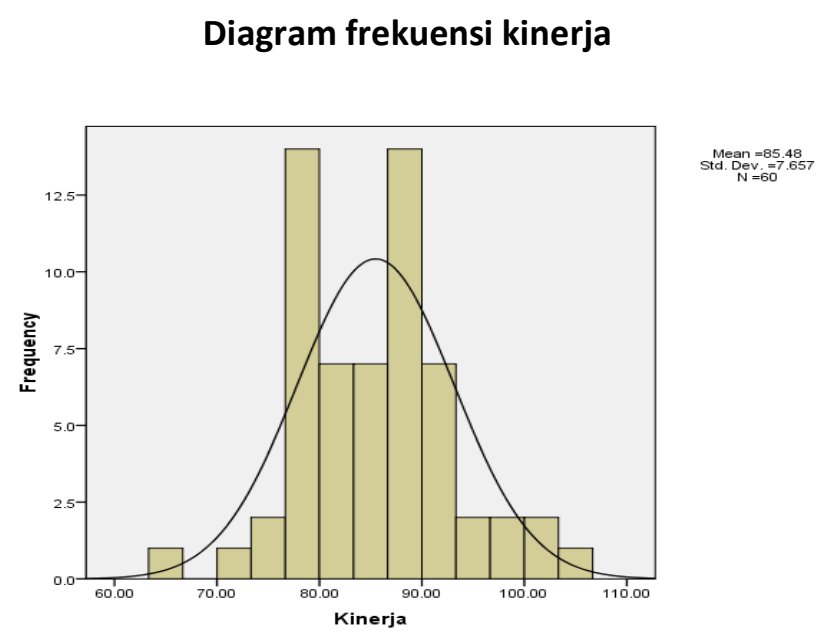

\begin{tabular}{|c|c|c|}
\hline No & Rentang Skor & Inetrpretasi \\
\hline 1 & $22,0-39,5$ & STS \\
\hline 2 & $39,6-57,1$ & TS \\
\hline 3 & $57,2-74,8$ & KS \\
\hline 4 & $74,9-92,3$ & S \\
\hline 5 & $92,4-110$ & SS \\
\hline
\end{tabular}

\section{Tabel interpretasi skor variabel kinerja ( $Y$ )}

Berdasarkan tabel interpretasi skor teoritis di atas, maka dapat kita ketahui bahwa kondisi kinerja karyawan pada PT. BEKAERT INDONESIA adalah Setuju dan ini mengartikan kondisi yang BAIK, hal ini di tunjukan oleh nilai rata - rata score pada tabel descriptive statistics yang menunjukan point 85,48 dan nilai ini berada pada kondisi BAIK pada tabel interpretasi skor teoritis.

Analisis yang berikutnya yaitu dengan menggunakan analisis koefeseien korelasi pearson. Tujuan dari analisis koefeseien korelasi pearson adalah ingin lebih meyakinkan bahwa pada kenyataannya terdapat hubungan antara variabel X (Kesehatan Dan Keselamatan Kerja) terhadap variabel Y (Kinerja Karyawan). Selain itu dapat diketahui hubungan kuat 
atau lemahnya antara variabel X (Kesehatan Dan Keselamatan Kerja) terhadap variabel Y (Kinerja Karyawan).

Melalui serangkaian analisis data yang telah dilakukan pada penelitian ini, maka hasil dalam penelitian ini yang berjudul Pengaruh Kesehatan Dan Keselamatan Kerja (K3) Terhadap Kinerja Karyawan pada PT. BEKAERT INDONESIA, dapat dianalisis sebagai berikut ini:

1. Melalui analisis deskriptif pada variabel X (K3) dan Y (Kinerja Karyawan) diperoleh hasil penelitian berupa :

a. Berdasarkan hasil dari penelitian melalui pengujian menggunakan tabel interpretasi skor teoritis, diketahui bahwa keadaan K3 pada PT.BEKAERT INDONESIA dalam kondisi baik.

b. Berdasarkan hasil dari penelitian melalui pengujian menggunakan tabel interpretasi skor teoritis, diketahui bahwa keadaan kinerja karyawan pada PT. BEKAERT INDONESIA dalam kondisi baik.

2. Berdasarkan perhitungan analisis koefesien korelasi pearson pada hubungan Kesehatan Dan Keselamatan Kerja terhadap Kinerja Karyawan pada PT. BEKAERT INDONESIA ditunjukan oleh nilai $r$ sebesar 0,615. Dengan nilai $r$ sebesar 0,615 dapat disimpulkan bahwa kesehatan dan keselamatan kerja mempunyai pengaruh yang positif dan kuat terhadap kinerja karyawan. Artinya apabila terjadi kenaikan kesehatan dan keselamatan kerja maka akan menyebabkan kenaikan juga pada kinerja karyawan pada PT. BEKAERT INDONESIA begitupun dengan sebaliknya.

3. Berikutnya dengan menggunakan uji signifikansi (uji t) untuk membuktikan keberartiannya, peneliti memperoleh hasil bahwa t hitung sebesar 5,621 dan nilai t tabel sebesar 1,670. Hal ini menunjukan bahwa nilai t hitung $(5,621)>t$ tabel $(1,670)$. Artinya H1 diterima, sehingga dapat disimpulkan bahwa kesehatan dan keselamatan kerja berpengaruh terhadap kinerja karyawan pada PT. BEKAERT INDONESIA.

4. Dengan menggunakan perhitungan analisis regresi sederhana pada pengaruh Kesehatan Dan Keselamatan Kerja terhadap Kinerja Karyawan pada PT. BEKAERT INDONESIA memiliki persamaan regresi berupa $\mathrm{Y}^{\prime}=39,12+0,587 \mathrm{X}$. Dari persamaan regresi tersebut Variable $X(\mathrm{~K} 3)$ bernilai positif yaitu sebesar 0,857. Itu artinya bahwa K3 mempunyai pengaruh yang positif atau berbanding lurus terhadap Kinerja Karyawan. Hal itu mengandung artian bahwa, kenaikan satu poin pada variabel Kesehatan Dan 
Keselamatan Kerja maka variabel Kinerja Karyawan juga akan mengalami kenaikan sebesar 0, 587 poin dan apabila terjadi penurunan satu poin pada K3 maka akan menurunkan Kinerja Karyawan sebesar 0,587 poin juga.

5. Kemudian dengan menggunakan Koefesien Determinasi diperoleh hasil bahwa K3 memiliki kontribusi pengaruh sebesar 37,82\% terhadap Kinerja Karyawan pada PT. BEKAERT INDONESIA. Sisanya yang sebesar 62,18\% mengandung arti bahwa Kinerja Karyawan juga dipengaruhi oleh faktor-faktor terkait lainnya.

\section{KESIMPULAN}

Kondisi K3 pada PT. BEKAERT INDONESIA ditunjukkan oleh rata - rata skor responden adalah sebesar 78,98 yang dapat diinterpretasikan BAIK. Kondisi Kinerja Karyawan pada PT. BEKAERT INDONESIA ditunjukkan oleh rata-rata skor responden adalah sebesar 85,48 yang dapat diinterpretasikan BAIK. Terdapat hubungan yang kuat antara K3 (X) dengan Kinerja karyawan (Y).

\section{DAFTA RPUSTAKA}

Dharma, Surya, Paradigma Baru : Manajemen Sumber Daya Manusia. Y Yogyakarta : Amara books., 2002

Gary, dessler, Manajemen Sumber Daya Manusia. Jakarta ; indeks, 2009

Hadipoetro, Sajidi, Manajemen Komprehensif Keselamatan Kerja, cetakan Pertama. Jakarta : Yayasan Patra Tarbiyyah Nusantara, 2014

Hasibuan, Malau S. p, Manajemen Sumber Daya Manusia. Jakarta : Bumi Aksara, 2002

J. Supranto, Statistik : Teori Dan Aplikasi, Cetakan Ketjuh. Jakarta : Erlangga, 2009 Mangkunegara, Evaluasi Kinerja SDM, cetakan Ketujuh. Bandung : PT. Refika Aditama., 2014

Mathis, R. L dan J. H, Jackson, Manajemen Sumber Daya Manusia. Jakarta : $\quad$ Salemba Empat, 2000

Mondy, R. W dan Noe, R. M, Human Resources Management $9^{\text {th }}$ ed. Prentice $\quad$ : Massachu Setts, 2005

Ramli, Soehatman, Sistem Manajemen Keselmatan Dan Kesehatan Kerja.

Jakarta : Dian Rakyat, 2010

Sugiyono, Statistika Untuk Penelitian. Bandung : Alfa beta, 2013 
Suma'mur, P. K, Hygene Perusahaan dan Keselematan Kerja, cetakan Kedua. Jakarta : CV. Haji Mas Agung, 1996

Sunyoto, Danang, Penelitian Sumber Daya Manusia. cetakan Pertama. Y Yogyakarta CAPS, 2015

Veithzal, Rivai, MSDM Untuk Perusahaan : dari teori ke praktik. Jakarta : PT. Raja Grafindo Persada, 2004

Wibowo, Manajemen Kinerja, edisi ke 3, Jakarta : PT. Raja Grafindo, 2016 
